\title{
AUDIT COMMITTEE CHARACTERISTICS, BOARD DIVERSITY, AND FRAUDULENT FINANCIAL REPORTING IN MALAYSIA
}

\author{
Marziana Madah Marzuki1 ${ }^{*}$, Noor Marini Haji-Abdullah ${ }^{1}$, Rohana Othman ${ }^{2}$, \\ Effiezal Aswadi Abdul Wahab ${ }^{3 * *}$, and Iman Harymawan ${ }^{4}$ \\ ${ }^{\text {I}}$ Faculty of Accountancy, Universiti Teknologi MARA \\ Cawangan Kelantan, Bukit Ilmu, 18500 Machang, Kelantan Malaysia \\ ${ }^{2}$ Department of Accounting, College of Business and Administration, \\ Female College in Aja, University of Hail, Hail 55471, Saudi Arabia \\ ${ }^{3}$ School of Accounting, Faculty of Business and Law, \\ Curtin University, Bentley 6102, Western Australia, Australia \\ ${ }^{4}$ Department of Accountancy, Faculty of Economics and Business, Universitas Airlangga, \\ Jalan Airlangga no. 4, Surabaya, East Java, Indonesia
}

Corresponding authors: marzianamadah@uitm.edu.my*; effiezal.abdulwahab@curtin. edu. $\mathrm{au}^{* *}$

Published online: 30 December 2019

To cite this article: Madah Marzuki, M., Haji-Abdullah, N.M., Othman, R., Abdul Wahab, E.A., and Harymawan, I. (2019). Audit committee characteristics, board diversity, and fraudulent financial reporting in Malaysia. Asian Academy of Management Journal, 24(2), 143-167. https://doi.org/10.21315/aamj2019.24.2.7

To link to this article: https://doi.org/10.21315/aamj2019.24.2.7

\begin{abstract}
We investigate the relationship between audit committee characteristics, board diversity, and the propensity of committing fraud among Malaysian firms. Based on a matched-pair sample of 64 observations for the years 2002-2014, we find limited evidence to suggest that audit committee characteristics matters. However, we find a negative relationship between the percentage of female directors and the likelihood of fraud. Results highlight the importance of the audit committee (in) effectiveness and the relative importance of female directors in Malaysia. Our results are robust when we consider a structural change in corporate governance policies in Malaysia.
\end{abstract}

Keywords: fraudulent financial reporting (FFR), audit committee, corporate governance, independence, expertise

(C) Asian Academy of Management and Penerbit Universiti Sains Malaysia, 2019. This work is licensed under the terms of the Creative Commons Attribution (CC BY) (http://creativecommons. org/licenses/by/4.0/). 


\section{INTRODUCTION}

Fraudulent financial reporting (FFR) has received considerable attention in recent years. According to Vlad et al. (2011), fraudulent financial statements can pose serious threats such as the erosion of public confidence, particularly investors' confidence in the reliability of the financial information reported. They also emphasised that FFR undermines the reliability, quality, transparency, and integrity of financial reporting. Extant literature finds that fraudulent financial reporting is associated with weak corporate governance (Beasley 1996; Beasley et al., 1999; Dechow et al., 1996; Dunn, 2004; Persons, 2006). Farber (2005) finds that fraud firms have poor governance as illustrated by fewer number and a lower percentage of external members in the board of directors, fewer audit committee meetings, fewer financial experts on the audit committees, a smaller percentage engaging Big 4 auditing firms, and a higher percentage of chief executive officer (CEO) duality. Corporate governance encompasses practices and procedures to ensure that a company is managed in such a way that it achieves its objectives. The purpose of corporate governance is to facilitate effective, entrepreneurial, and prudent management that can lead to the long-term success of the company (Council, Financial Reporting, 2012). Thus, any practices that lead to inefficiency of corporate governance practices are described as poor corporate governance and is expected to lead to corporate failure such as FFR. The term "poor corporate governance" has been covered extensively in prior research works of corporate governance such as Cornelius (2005), Dittmar and Mahrt-Smith (2007), and Hoechle et al. (2012). Despite the findings, little is known whether these corporate governance characteristics hold the potential to mitigate FFR especially in developing countries such as Malaysia, which have different institutional settings from developed countries like the United States.

Hasnan et al. (2013) provide the initial evidence on FFR in Malaysia, in which they find that firms engaging in fraudulent activities have a high level of earnings management prior to committing fraud. Hasnan et al. (2014) suggest that firms might involve in fraudulent activities because of accounting failure and poor corporate governance. Md Nasir et al. (2018) then extend Hasnan et al.'s (2013; 2014) research by examining whether these firms engage in either real or accruals earnings management prior to committing fraud. Based on a sample of 65 fraud and non-fraud firms, they found fraud firms engaging in manipulating production costs. We extend these papers in several ways. First, we focus on audit committee characteristics (expertise, meetings, and tenure), and board diversity (female directors), in relation to FFR. We focus on audit committee characteristics as audit committee plays more direct role in monitoring the board of directors (Xie et al., 2003) and thus have more influence on the information content of earnings 
(Anderson et al., 2003). Unlike the above-mentioned studies; our data cover a more extended period (2002-2014), which gives a better scope in understanding the role of these governance factors.

This study takes advantage of the increasing role of women in boardrooms in Malaysia on FFR. On 27 June 2011, the then Prime Minister Dato' Seri Najib Tun Razak announced that the Malaysian cabinet had approved a policy whereby corporate firms in the private sector must achieve at least 30\% representation of women in decision-making positions. Following the announcement, Securities Commission Malaysia (SC) and Bursa Malaysia have taken an initiative to promote diversity and inclusiveness. ${ }^{1}$ A subsequent announcement made by the government on 15 September 2011 drew attention to as the government is studying the proposal on how to boost women's participation in the corporate sector. Thus, the investigation on the role of women in audit committee as well as board of directors is timely and has policy implications.

After controlling for other governance variables and institutional setting variables in Malaysia, we find limited evidence that audit committee characteristics can reduce the likelihood of fraud. Contrary to expectations, independent audit committee members are positively associated with FFR, while grey audit committee members are negatively associated with FFR, warranting further and thorough investigation on the audit committees in Malaysia. The relationship between the percentage of women on the board of directors and FFR results in a negative relationship, highlighting the vital role of women in boardrooms.

\section{LITERATURE REVIEW AND HYPOTHESES DEVELOPMENT}

\section{Audit Committee Composition}

Several empirical studies have shown that boards composed of external directors who are mainly independent are more effective in their monitoring role. Previous studies (Dechow et al., 1996, Klein, 2002; Peasnell et al., 2000; Xie et al., 2003) indicate that the independence of audit committee is more efficient in constraining earnings management, and thus, have lower earnings manipulation. Other studies (Beasley, 1996; Farber, 2005) have also shown that an independent audit committee is less likely to commit fraud. Abbott et al. (2000) state that external audit committee directors play two crucial roles in demanding financial reporting quality, which is the preservation of auditors' reputation in enhancing financial reporting quality and mitigating shareholder lawsuits against financial statements fraud. 
Despite the evidence on the monitoring role of external directors, there is little evidence found on the different impact of solely independent and grey directors since past studies treating these distinct group as homogenous (Wan Hussin, 2009). An independent director is an external director who has no affiliation with the firm other than being on the board of directors, whereas non-independent directors are external directors who have some non-board affiliation with the firm (Beasley 1996). Felo and Solieri (2009) state that directors can be classified as grey for various reasons such as family relationship, formerly worked for the firm, or business relationship with the firm.

Raghunandan et al. (2001) find that audit committees can only perform better if the audit committee is comprised solely of independent directors and with at least one member having an accounting or finance background. Their result is also supported by Mustafa and Youssef (2010), which find that an independent audit committee member is only useful in reducing the occurrence of misappropriation of assets if he or she is also a financial expert.

Alternatively, from the resource dependency perspective, grey directors could play an important role in advising as they involve in strategic business decision making through their affiliations with the firm. Hsu and Wu (2014) stress that the effectiveness of grey directors is rooted in the collaborative board model in which the collaborative working relationships among its members are enabling to reinforce strategic board function through the flow of information in the boardroom. Their result supports that firms with a large proportion of grey directors on their boards are less likely to fail. Their result is consistent with previous studies which find that grey directors enhance disclosure quality (Felo \& Solieri, 2009) and corporate transparency (Wan Hussin, 2009). Based on the ambiguous relationship on audit committee composition, we predict the following non-directional hypothesis, stated in the alternative form:

$\mathrm{H}_{1 \mathrm{a}}$ : There is a relationship between the percentage of independent audit committee and the likelihood of fraudulent financial reporting

$\mathrm{H}_{1 \mathrm{~b}}$ : There is a relationship between the percentage of grey audit committee and the likelihood of fraudulent financial reporting

\section{Audit Committee Expertise}

He et al. (2009) state that having at least one financial expert in the audit committee enables the augmentation of the committee's effectiveness since financial experts are required to lead the committee in identifying and raising knowledgeable 
questions that can challenge the management. An expert audit committee member can assist external auditors in negotiating and challenging management in relation to accounting estimates, judgments, and applications of accounting principles (Deli \& Gillan, 2000; DeZoort \& Salterio, 2001). Krishnan and Visvanathan (2008) argue that an audit committee with financial accounting expertise can enhance conservatism since they can help firms to assess justifications given by the management as they have experience-based and well-developed frameworks to measure account's conservatism.

Farber (2005) and Abbott et al. (2004) supported the notion that financial expertise is an important characteristic of an audit committee in controlling managers' behaviours by showing that financial expertise possessed by audit committees can strengthen monitoring and oversight roles of audit committees in the financial reporting process. Previous studies (Krishnan, 2005; Zhang et al., 2007; Lo et al., 2010) also verified that audit committee expertise could help firms to constrain management's opportunistic behaviour, as they understand the complexities of financial reporting presented by the management.

In contrast, $\mathrm{He}$ et al. (2009) argue that even though an expert audit committee is expected to ask knowledgeable questions that can challenge the management, such ability may not require expertise. It was found that people with no formal training either in accounting or finance can be as insightful (or even more) as those with formal training, maybe because they have practical management experience (Association for Investment Management and Research, 1999).

The effects of audit committee expertise on the quality of financial reporting produce mixed results. Previous studies have documented that audit committee expertise can enhance earnings conservatism (Krishnan \& Visvanathan, 2008), reduce fraudulent reporting of financial statements (Abbott et al., 2004; Farber, 2005), is less likely to be associated with incidences of internal control problems (Krishnan, 2005; Zhang et al., 2007), less likely to engage in transfer pricing manipulations (Lo et al., 2010), reduce aggressive earnings management (Carcello et al., 2006), and reduce misappropriation of assets (Mustafa \& Meier, 2006; Chapple et al., 2009).

On the other hand, Xie et al. (2003) find that the percentage of external legal and financial members of an audit committee is unrelated to the current discretionary accruals. Similarly, Carcello and Neal (2003) find that different expertise presents different impacts on financial reporting quality and managerial influence plays a vital role in influencing the use of their expertise. Based on the above-mentioned arguments, we posit a non-directional hypothesis, stated in the alternative form: 
$\mathrm{H}_{2}$ : There is a relationship between the percentage of audit committee members with financial accounting expertise and the likelihood of fraudulent financial reporting

\section{Audit committee meetings}

The frequency of audit committee meetings is a measure of the demand for monitoring a firm's financial reporting process (Goodwin-Stewart \& Kent, 2006; Engel et al., 2010) and is believed to be translated into higher financial reporting transparency. Audit committee meetings are viewed as an important element by the creditors in their relationship with the firms (Anderson et al., 2004). The 1999 Blue Ribbon Committee (BRC) report, likewise, advocates that audit committees can best assure the quality of the financial statements by having at least four meetings a year (Morrissey, 2000). Zhang et al. (2007) state that firms need additional meetings in order to solve problems such as internal control weaknesses. Abbott et al. (2004) and Anderson et al. (2004) state that meeting frequency may indirectly provide information on how active and valuable audit committee monitoring is and the committee's diligence in carrying out their responsibilities.

Abbott et al. (2004) find that firms are more likely to appoint industry-specialist auditors if independent audit committees meet at least twice a year. Beasley et al. (2000) find that the audit committees of fraudulent firms meet less often relative to non-fraud firms. Abbott et al. (2004) find that the number of audit meetings is negatively associated with the frequency of accounting restatements. Anderson et al. (2004) showed that meetings frequency is associated with lower costs of debt financing, lower yield spreads, and is associated with the types of auditor change made by the company. Therefore, this study posits that:

$\mathrm{H}_{3}$ : There is a relationship between the number of audit committee meetings and fraudulent financial reporting

\section{Board Diversity}

The recent proposals of governance reforms on the importance of gender diversity have been raised to highlight the difference between men and women in many terms including personality, communication style, educational background, and career experience as has been stressed by previous researches (Buss, 2005; Feingold, 1994). Francis et al. (2015) point out that female chief financial officers (CFOs) are more sensitive to various types of risk than male CFOs. Thus, women are generally more risk-averse than men (Eckel \& Grossman, 2008; Croson \& Gneezy, 2009). Huang and Kisgen (2013) find that female CFOs are less likely 
to make a significant number of acquisitions. Nevertheless, when they do make acquisitions, they exhibit higher announcement returns compared to those made by firms with male CFOs. Huang and Kisgen (2013) also find that female CFOs are less likely to issue debt and are more likely to reduce the debt ratio than male CFOs.

Nevertheless, the prejudices against women still play around the mind and influence the mentality of others with the perception that women are more problematic due to conditions such as maternity breaks and household responsibilities. Hiring women will mean hiring more cost as firms need to provide more infrastructure and more flexible working policy to support women's working condition. Previous researchers find mixed results on gender diversity. Adams and Ferreira (2009) find that female board members improve corporate governance but decrease firm performance. Dyreng et al. (2010) do not find that executive gender affects corporate tax avoidance. Ge et al. (2011) do not find that CFO gender affects discretionary accruals. Some studies show that female directors may play an insignificant role in environmental matters due to sex-based biases (Galbreath, 2011; Rodriguez-Dominguez et al., 2009). Ferreira (2010) notes that firms gain social benefits in promoting women to the board. Women's presence increases accountability and improves communication between the board and stakeholders. In other words, it increases non-financial measures such as customer satisfaction, gender representation and corporate social responsibility (Terjesen et al., 2009).

Despite mixed evidence, this study believes that the presence of women on board will eventually contribute to better firm performance and the firm's survival. Therefore, this study posits that:

$\mathrm{H}_{4}$ : There is a negative relationship between female directors on the board and the likelihood of fraudulent financial reporting

\section{RESEARCH METHOD}

\section{Dependent Variable}

The dependent variable used in the analysis is FFR, which takes the value of 1 if the firm commits FFR, zero otherwise. This variable is identified from the SC's website. Since FFR is defined as intentional misrepresentation of a firm's financial statements with the aim to give investors a mistaken impression about the firm's operating performance and profitability, the firms included as samples are those that commit FFR such as submitting misleading statement to Bursa Malaysia 
Securities Berhad, submission of false statements and/or information in prospectus (s.55 of the Securities Commission Act), and submission of false information in Annual Report (s.122B of the Securities Industries Act).

\section{Independent and Control Variables}

The independent variables used in this study are audit committee characteristics which are the composition of the audit committee, audit committee expertise, and audit committees' number of meetings. This study included several control variables. These control variables are included in order to capitalise on several regulatory changes in Malaysia, and these variables are expected to play a significant role in influencing FFR. Some financial and institutional variables are also included. We include financial variables total debt-to-total asset (DEBT) and total asset (SIZE) to represent debt and firm size. For institutional variables, we include political connection (POLCON) and family connection (FAMILY) to represent Malaysia's institutional setting. The influence and dominance of family presence and ownership in Malaysia have been well documented (Claessens \& Fan, 2002; Jaggi et al., 2009). Capital control from family dominance and political connections in Malaysia's economy has led to an increase in cronyism (Johnson \& Mitton, 2003) and thus are expected to influence FFR. Hasnan and Hussain (2015) quoted that corporate ownership in East Asian countries is concentrated in large controlling shareholders, specifically, the family and the individual. Krishnan and Peytcheva (2019) find that auditors assess the risk of fraud as higher for family firms as compared to non-family firms. Previous research has indicated that debt (Persons, 2006) and political connection (Hasnan et al., 2013) are among the important factors to be associated with FFR. All independent and control variables are summarised in Table 1.

Table 1

Operational definitions

\begin{tabular}{|c|c|c|}
\hline Variables & Symbol & Operationalisation \\
\hline \multicolumn{3}{|l|}{ Dependent variable } \\
\hline $\begin{array}{l}\text { The propensity of fraudulent } \\
\text { financial reporting }\end{array}$ & FFR & $\begin{array}{l}\text { A dummy variable coded } 1 \text { if the firm issued } \\
\text { fraudulent financial reporting, and } 0 \text { otherwise }\end{array}$ \\
\hline \multicolumn{3}{|l|}{ Independent variables } \\
\hline \multirow[t]{2}{*}{ Audit committee independence } & AC_IND & Percentage of independent audit committee \\
\hline & AC_GREY & $\begin{array}{l}\text { Percentage of non-independent non-executive/ } \\
\text { grey audit committee }\end{array}$ \\
\hline Audit committee expertise & AC_ACCT & $\begin{array}{l}\text { Percentage of audit committee with financial } \\
\text { accounting expertise }\end{array}$ \\
\hline
\end{tabular}

(continued on next page) 
Table 1: (continued)

\begin{tabular}{|c|c|c|}
\hline Variables & Symbol & Operationalisation \\
\hline & AC_FIN & $\begin{array}{l}\text { Percentage of the audit committee with } \\
\text { financial expertise }\end{array}$ \\
\hline & $\begin{array}{l}\mathrm{AC} \\
\mathrm{NON}\end{array}$ & $\begin{array}{l}\text { Percentage of the audit committee with non- } \\
\text { financial expertise }\end{array}$ \\
\hline Audit committee meeting & AC_MEET & Number of audit committee meetings \\
\hline Board gender & $\begin{array}{l}\mathrm{BOD}_{-} \\
\text {WOMEN }\end{array}$ & Percentage of women on board of directors \\
\hline Audit committee gender & AC_MALE & Percentage of male audit committee \\
\hline \multicolumn{3}{|l|}{ Control variables } \\
\hline Board duality & DUALITY & $\begin{array}{l}\text { A dummy variable with a value of } 1 \text { when the } \\
\text { chairman of the board of directors is the CEO } \\
\text { or president of a company in the prior year to } \\
\text { the occurrence of FFR }\end{array}$ \\
\hline \multirow[t]{2}{*}{ Audit committee tenure } & $\begin{array}{l}\mathrm{AC}_{-} \\
\text {TENURE }\end{array}$ & $\begin{array}{l}\text { Number of tenure of independent directors } \\
\text { in audit committee divided by the number of } \\
\text { independent directors in the audit committee }\end{array}$ \\
\hline & $\begin{array}{l}\text { D_AC_- } \\
\text { TENURE }\end{array}$ & $\begin{array}{l}\text { A dummy variable equal to } 1 \text { if total tenures of } \\
\text { independent audit committee equal to nine or } \\
\text { less than nine years }\end{array}$ \\
\hline \multirow[t]{2}{*}{ Audit committee directorships } & AC_MULTI & $\begin{array}{l}\text { Number of directorships of independent } \\
\text { directors in audit committee divided by the } \\
\text { number of independent directors in the audit } \\
\text { committee }\end{array}$ \\
\hline & $\begin{array}{l}\mathrm{D}_{\overline{\mathrm{AULT}}} \mathrm{AC} \\
\mathrm{MUL}\end{array}$ & $\begin{array}{l}\text { A dummy variable equal to } 1 \text { if the total } \\
\text { number of directorships of the independent } \\
\text { audit committee is equal to five or less than } \\
\text { five }\end{array}$ \\
\hline Political connection & POLCON & $\begin{array}{l}\text { A dummy variable; coded as } 1 \text { if the firms have } \\
\text { political connection and } 0 \text { otherwise. }\end{array}$ \\
\hline Family connection & FAMILY & $\begin{array}{l}\text { A dummy variable; coded as } 1 \text { if one of the } \\
\text { directors have family connection }\end{array}$ \\
\hline Debt & DEBT & Total debt to total asset \\
\hline Firm size & SIZE & Total asset \\
\hline
\end{tabular}

\section{Research Model}

In order to analyse the association between our test variables and FFR, we use the following cross-sectional logistic regression model: 
$\mathrm{FFR}_{\mathrm{it}}=\beta_{0}+\beta_{1}$ Audit Committee Composition $_{\mathrm{i}(t-1)}+\beta_{2}$ Audit Committee Expertise $_{\mathrm{i}(t-1)}$ $+\beta_{3}$ Audit Committee Meetings $_{\mathrm{i}(\mathrm{t}-1)}+$ Women $_{(\mathrm{t}-1)}+\beta_{5}$ Control variables $_{\mathrm{i}(\mathrm{t}-1)}+\varepsilon$

In order to test each hypothesis discussed above, we run the logit model using several sub-samples based on three different criteria which are audit committee composition, audit committee expertise, and audit committee meetings. The models are further discussed in the analysis of results.

\section{Sample Selection}

This study utilises a sample of firms identified by the SC for fraudulent financial reporting between 2002 and 2014. The samples selected for this study consist of 51 fraud firms listed in the SC enforcement release. However, 12 firms were excluded due to the unavailability of data. One company is excluded due to the firm's delisting, and three firms were excluded since the firms have been admitted to the MESDAQ market. Finally, three firms are excluded because we were unable to locate matching firms. Therefore, the final sample consists of 32 fraud firms identified by the SC for fraudulent financial reporting. ${ }^{2}$ This 32 fraud firms then are matched with 32 non-fraud firms which brings the total samples to 64 firms.

Each of the sample firms was then matched with non-fraud control firms based on two criteria, which are size as measured by total assets and industry effects. Fraud firms are matched with non-fraud firms within $20 \%$ of its size, and they are in the same industry if there is more than one matching firm for each firm; thus, the firm with the closest size is selected (Jia et al., 2009).

\section{Data Description}

Table 2 provides the descriptive statistics of the independent and control variables for the whole sample. Overall, the result indicates that an average $75 \%$ of the audit committee consists of non-executive directors, with $65 \%$ solely independent, and $10 \%$ are grey directors. The result indicates that there are several firms, which are still appointing executive directors as part of their audit committee's composition. Audit committees, which are purely accounting expertise, is only $34 \%$. Only $36 \%$ of the audit committee are financially literate, while the remaining are nonfinancial literate. The result indicates that in average the sample does not comply with the Malaysian Code on Corporate Governance (MCCG), which emphasises that all members of audit committees should be financially literate and at least one should be a member of an accounting association or body. The average number of meetings conducted by the firms is 4 . This is consistent with what has been suggested that audit committees can best assure the quality of financial statements 
by having at least four meetings a year (Morrissey, 2000). In terms of gender, 93\% of the audit committee are male, which means that women only represent $7 \%$ of the audit committee. Meanwhile, only $9 \%$ of the board of directors are women.

In terms of new MCCG 2012 requirement which are board duality and tenure, the result indicates that in the prior year to the occurrence of FFR, $21.9 \%$ of the firms have the chairman of the board of directors who are also the CEO or president of the firms. The mean tenure for the sample of this study is 64 months, which is equal to about 5 years tenure. Nevertheless, the maximum tenure for this sample is 275 months, which is equal to about 23 years. In terms of MCCG requirement for the tenure to be less than 9 , only $48 \%$ of the firms' audit committee has a total tenure equal to or less than nine years. The average directorships for the sample are 2 directorships, and the maximum directorships are 8 . About $65 \%$ of the firms their audit committee have multiple directorships less than 5. In terms of Malaysia's institutional setting, $26.6 \%$ of the sample comprises of politically connected firms, and $51.6 \%$ are family connected. The result supports that Malaysia is among the countries in Asia that has high percentage of family connection among the listed firms (Jaggi et al., 2009). The means for total asset log and debt to total asset (DTA) are 19.026 and 1.099, respectively.

Table 2

Descriptive statistics $(n=64)$

\begin{tabular}{llllll}
\hline & Mean & Median & Maximum & Minimum & Std. dev. \\
\hline Panel A: Main Variables & & & & & \\
AC_IND & 65.444 & 66.670 & 100.000 & 25.000 & 15.645 \\
AC_GREY & 9.974 & 0.000 & 66.670 & 0.000 & 17.247 \\
AC_ACCT & 34.375 & 33.333 & 75.000 & 0.000 & 19.833 \\
AC_FIN & 36.327 & 33.330 & 100.000 & 0.000 & 21.014 \\
AC_NONFIN & 64.324 & 66.670 & 100.000 & 0.000 & 21.176 \\
AC_MEET & 4.328 & 5.000 & 7.000 & 0.000 & 1.624 \\
BOD_WOMEN & 0.090 & 0.000 & 0.900 & 0.000 & 0.194 \\
AC_MALE & 0.931 & 1.000 & 1.000 & 0.333 & 0.146 \\
Panel B: Control Variables & & & & & \\
AC_TENURE & 63.758 & 46.750 & 274.667 & 6.000 & 52.775 \\
AC_MULTI & 2.341 & 2.000 & 8.667 & 0.000 & 1.858 \\
SIZE & 19.026 & 19.041 & 22.459 & 16.405 & 1.158 \\
DEBT & 1.099 & 0.485 & 18.670 & 0.010 & 2.725 \\
\hline
\end{tabular}




\section{RESULTS}

\section{Multivariate}

Table 3 represents our main logit regression results of the relationship between audit committee characteristics and FFR. Models 1, 3, and 5 were conducted to test the relationship between audit committee characteristics and fraudulent financial reporting by operationalising percentage of independent non-executive directors. Meanwhile, models 2, 4, and 6 were for by operationalising percentage of grey directors. The independent non-executive and grey directors were run using different expertise of audit committees, which are the percentage of audit committee with accounting expertise, percentage of audit committee with financial literacy and percentage of audit committee with non-financial expertise. The result indicates that none of the audit committees' characteristics which are audit committee composition, audit committee expertise, and audit committee meetings have significant relationship with fraudulent financial reporting. The result is consistent with univariate analysis, which indicates that there is no significant difference between fraud and non-fraud firms in terms of these audit committee characteristics.

Nevertheless, we find a significant negative relationship between percentages of women in board of directors and political connection with FFR in all the six models. The result highlights the important role of women in the board of directors in reducing the likelihood of FFR. Thus, $\mathrm{H}_{4}$ is supported. The result in univariate analysis indicates that fraud firms have only 5\% of women in board of directors while non-fraud firms have $13 \%$ women in their board of directors. It shows that non-fraud firms have taken the initiative in line with the announcement made by the government to boost women's presence in the workforce. The result also highlights the advantages of having women on board of directors.

The significant negative relationship between political connection and fraudulent financial reporting support the previous studies which argued that the role of political connection in a company is not to enhance shareholder value but rather to provide preferential treatment as they can provide easier access to funds and, thus, firms can easily avoid bankruptcy (Claessens \& Fan, 2002, Khwaja \& Mian, 2005, Faccio, 2006). Secondly, the politically connected firms may use their connections to interfere and exploit control over regulatory bodies and, hence, can easily reduce oversight over the company in return for bribes and political support. Hasnan et al. (2013) asserted that political connection could make FFR more challenging to be detected as politicians may use their connections to hide questionable practices and avoid regulatory scrutiny. 
The variance inflation factor (VIF) for regressions in Table 3 ranges between 1.607 and 1.813 , suggesting no multicollinearity issue.

Table 3

Main regression

\begin{tabular}{|c|c|c|c|c|c|c|}
\hline & 1 & 2 & 3 & 4 & 5 & 6 \\
\hline Variable & FFR & FFR & FFR & FFR & FFR & FFR \\
\hline \multirow[t]{2}{*}{ Intercept } & -4.798 & -3.400 & -3.779 & -2.515 & -4.228 & -3.11 \\
\hline & -1.232 & -0.926 & -0.955 & -0.67 & -1.179 & -0.926 \\
\hline \multirow[t]{2}{*}{ AC_IND } & 0.018 & & 0.017 & & 0.016 & \\
\hline & 1.631 & & 1.469 & & 1.390 & \\
\hline \multirow[t]{2}{*}{ AC_GREY } & & -0.016 & & -0.016 & & -0.016 \\
\hline & & -1.273 & & -1.260 & & -1.239 \\
\hline \multirow[t]{2}{*}{ AC_ACCT } & 0.464 & 0.31 & & & & \\
\hline & 0.484 & 0.323 & & & & \\
\hline \multirow[t]{2}{*}{ AC_FIN } & & & -0.004 & -0.005 & & \\
\hline & & & -0.429 & -0.528 & & \\
\hline \multirow[t]{2}{*}{ AC_NONFIN } & & & & & 0.006 & 0.007 \\
\hline & & & & & 0.705 & 0.818 \\
\hline \multirow[t]{2}{*}{ AC_MEET } & 0.034 & 0.060 & 0.044 & 0.071 & 0.046 & 0.074 \\
\hline & 0.276 & 0.494 & 0.362 & 0.585 & 0.382 & 0.637 \\
\hline \multirow[t]{2}{*}{ BOD_WOMEN } & $-2.933^{*}$ & $-2.859^{* *}$ & $-3.263^{*}$ & $-3.167^{* *}$ & $-3.358^{*}$ & $-3.28^{* *}$ \\
\hline & -1.704 & -2.022 & -1.710 & -1.974 & -1.741 & -2.017 \\
\hline \multirow[t]{2}{*}{ AC_MALE } & -0.974 & -1.295 & -1.409 & -1.742 & -1.542 & -1.865 \\
\hline & -0.487 & -0.690 & -0.676 & -0.879 & -0.737 & -0.945 \\
\hline \multirow[t]{2}{*}{ DUALITY } & 0.031 & -0.082 & 0.076 & -0.042 & 0.098 & -0.017 \\
\hline & 0.072 & -0.187 & 0.179 & -0.097 & 0.229 & -0.039 \\
\hline \multirow[t]{2}{*}{ AC_TENURE } & -0.002 & -0.002 & -0.003 & -0.002 & -0.003 & -0.003 \\
\hline & -0.730 & -0.452 & -0.992 & -0.687 & -1.063 & -0.741 \\
\hline \multirow[t]{2}{*}{ AC_MULTI } & -0.016 & -0.003 & -0.02 & -0.007 & -0.019 & 0.003 \\
\hline & -0.158 & -0.025 & -0.191 & -0.069 & -0.18 & 0.102 \\
\hline \multirow[t]{2}{*}{ POLCON } & $-1.082^{* *}$ & $-0.888^{* *}$ & $-1.084^{* *}$ & $-0.902^{*}$ & $-1.073^{* *}$ & -0.894 \\
\hline & -2.240 & -1.957 & -2.247 & -1.956 & -2.224 & -1.927 \\
\hline \multirow[t]{2}{*}{ FAMILY } & -0.194 & -0.300 & -0.176 & -0.284 & -0.16 & -0.265 \\
\hline & -0.520 & -0.731 & -0.464 & -0.686 & -0.420 & -0.640 \\
\hline
\end{tabular}


Table 3: (continued)

\begin{tabular}{lcccccc}
\hline & 1 & 2 & 3 & 4 & 5 & 6 \\
\hline Variable & FFR & FFR & FFR & FFR & FFR & FFR \\
\hline SIZE & 0.241 & 0.247 & 0.234 & 0.241 & 0.237 & 0.243 \\
& 1.360 & 1.425 & 1.326 & 1.402 & 1.357 & 1.417 \\
DEBT & $0.696^{*}$ & 0.769 & $0.613^{*}$ & 0.682 & 0.605 & 0.681 \\
& 1.749 & 1.588 & 1.649 & 1.473 & 1.633 & 1.491 \\
N & 64 & 64 & 64 & 64 & 64 & 64 \\
Pseudo R2 & 0.282 & 0.277 & 0.269 & 0.279 & 0.245 & 0.285 \\
LR statistic & $22.618^{* *}$ & $22.579^{* *}$ & $22.586^{* *}$ & $22.742^{* *}$ & $22.846^{* *}$ & $23.083^{* *}$ \\
\hline
\end{tabular}

Notes: Please refer to Table 1 for operational definitions; ${ }^{*},{ }^{* *}$, and ${ }^{* * *}$ present significant levels at $10 \%, 5 \%$, and $1 \%$, respectively

In order to test the robustness of our result, we try to run all the models again using a dummy variable for tenure and directorships. We set the limitation of tenure and directorship as the benchmark of the dummy variable in order to test whether new requirements made by the government can reduce FFR. We find interesting results, as there is a significant positive relationship between the percentage of independent audit committee and FFR. In contrast, we find significant negative relationship between percentage of grey audit committee and FFR in all the 6 models.

The result indicates that independent non-executive directors enhance FFR; meanwhile, grey directors' decreases the likelihood of fraudulent financial reporting. We offer the following reasons on the inverse relationship. First, the direction may indicate that having external directors does not necessarily bring positive effect to the firms, as independent directors are not familiar with the operation of the firms. Bhagat and Black (2002) find no evidence that firms with more independent boards perform better. Instead, they provide evidence that there are hints that these firms suffer worse performance than firms with lesser independent directors firms. Besides, many independent directors own only a small amount of their company's shares and hence, have limited incentives to monitor managers. ${ }^{3}$

Table 4

Main regressions with indicator variables

\begin{tabular}{lcccccc}
\hline & 1 & 2 & 3 & 4 & 5 & 6 \\
\hline Variable & FFR & FFR & FFR & FFR & FFR & FFR \\
\hline Intercept & -5.358 & -3.280 & -4.509 & -2.570 & -4.603 & -2.832 \\
\hline & & & & & \multicolumn{2}{c}{ (continued on next page) }
\end{tabular}


Table 4: (continued)

\begin{tabular}{|c|c|c|c|c|c|c|}
\hline & 1 & 2 & 3 & 4 & 5 & 6 \\
\hline \multirow[t]{2}{*}{ Variable } & FFR & FFR & FFR & FFR & FFR & FFR \\
\hline & -1.427 & -0.925 & -1.185 & -0.709 & -1.297 & -0.834 \\
\hline \multirow[t]{2}{*}{ AC_IND } & $0.026^{* *}$ & & $0.024^{* *}$ & & $0.024^{* *}$ & \\
\hline & 2.345 & & 2.220 & & 2.167 & \\
\hline \multirow[t]{2}{*}{ AC_GREY } & & $-0.021^{* *}$ & & $-0.021^{* *}$ & & $-0.021^{* *}$ \\
\hline & & -2.004 & & -1.997 & & -1.989 \\
\hline \multirow[t]{2}{*}{ AC_ACCT } & 0.841 & 0.612 & & & & \\
\hline & 0.865 & 0.627 & & & & \\
\hline \multirow[t]{2}{*}{ AC_FIN } & & & -0.001 & -0.002 & & \\
\hline & & & -0.055 & -0.189 & & \\
\hline \multirow[t]{2}{*}{ AC_NONFIN } & & & & & 0.003 & 0.005 \\
\hline & & & & & 0.320 & 0.517 \\
\hline \multirow[t]{2}{*}{ AC_MEET } & 0.001 & 0.026 & 0.012 & 0.038 & 0.015 & 0.042 \\
\hline & 0.010 & 0.209 & 0.096 & 0.306 & 0.122 & 0.334 \\
\hline \multirow[t]{2}{*}{ BOD_WOMEN } & 0.077 & -0.062 & 0.115 & -0.036 & 0.130 & -0.017 \\
\hline & 0.169 & -0.139 & 0.261 & -0.082 & 0.296 & -0.039 \\
\hline \multirow{2}{*}{ AC_MALE } & -0.151 & -0.290 & -0.070 & -0.217 & -0.045 & -0.191 \\
\hline & -0.371 & -0.709 & -0.169 & -0.519 & -0.110 & -0.464 \\
\hline \multirow[t]{2}{*}{ DUALITY } & 0.494 & 0.297 & 0.459 & 0.284 & 0.447 & 0.272 \\
\hline & 1.210 & 0.743 & 1.118 & 0.709 & 1.083 & 0.678 \\
\hline \multirow[t]{2}{*}{ D_AC_TENURE } & $-1.115^{* *}$ & $-0.836^{*}$ & $-1.100^{* *}$ & $-0.835^{*}$ & $-1.092^{* *}$ & $-0.826^{*}$ \\
\hline & -2.270 & -1.784 & -2.248 & -1.780 & -2.239 & -1.768 \\
\hline \multirow[t]{2}{*}{ D_AC_MULTI } & -0.394 & -0.468 & -0.366 & -0.451 & -0.351 & -0.433 \\
\hline & -1.036 & -1.168 & -0.959 & -1.122 & -0.913 & -1.075 \\
\hline \multirow[t]{2}{*}{ POLCON } & 0.260 & $0.275^{*}$ & 0.246 & 0.265 & 0.246 & 0.265 \\
\hline & 1.488 & 1.673 & 1.407 & 1.611 & 1.422 & 1.634 \\
\hline \multirow[t]{2}{*}{ FAMILY } & $0.747^{*}$ & $0.797^{*}$ & $0.673^{*}$ & 0.729 & $0.660^{*}$ & 0.716 \\
\hline & 1.898 & 1.787 & 1.708 & 1.638 & 1.684 & 1.612 \\
\hline $\mathrm{N}$ & 64 & 64 & 64 & 64 & 64 & 64 \\
\hline Pseudo R2 & 0.282 & 0.277 & 0.269 & 0.279 & 0.245 & 0.285 \\
\hline LR statistic & $24.951^{* *}$ & $24.670^{* *}$ & $24.338^{* *}$ & $24.369^{* *}$ & $24.422^{* *}$ & $24.559^{* *}$ \\
\hline
\end{tabular}

Notes: Please refer to Table 1 for operational definitions; ${ }^{*},{ }^{* *}$, and ${ }^{* * *}$ present significant levels at $10 \%, 5 \%$, and $1 \%$ respectively. 


\section{Endogeneity}

Based on corporate governance literature (Lim, 2011), the findings of this study may be subject to omitted variables biases resulting from the omission of other governance mechanisms that can influence FFR. Therefore, this study adopted a two-stage least squares (2SLS) approach to control for potential endogeneity problems. The approach requires the identification and use of an instrument (exogenous variable) which has an impact of on the fraudulent financial reporting only through audit committee characteristics without any direct influence on fraudulent financial reporting. This study uses institutional shareholdings as an instrumental variable because it is more likely that institutional shareholdings are associated with audit committee characteristics without having direct effect on fraudulent financial reporting. Institutional shareholdings can act as pressuresensitive investors that can influence the role of the audit committee (PuchetaMartinez, 2014).

We perform the 2SLS regressions and yield statistically similar results. Specifically, untabulated statistics for the test are $t=-2.000$ for BOD_WOMEN, -2.143 for POLCON and 2.131 for DEBT. Overall, the results for the 2SLS provide further support to the main findings reported in Table 4 and 5.

\section{Further analyses}

We extend our tests by first, running the regression with robust standard errors with a non-linear DEBT variable (DEBT2). The robust standard error is to control for heteroscedasticity in the regression. Results, as presented in Table 5, remain statistically similar to the main regression, suggesting that the earlier results in Table 4 is robust.

Table 5

Main regression with robust standard errors

\begin{tabular}{lcccccc}
\hline & 1 & 2 & 3 & 4 & 5 & 6 \\
\hline \multirow{2}{*}{ INTERCEPT } & FFR & FFR & FFR & FFR & FFR & FFR \\
& -9.600 & -7.315 & -7.572 & -5.528 & -8.195 & -6.454 \\
& -1.26 & -1.04 & -0.98 & -0.78 & -1.19 & -1.02 \\
AC_IND & $0.032^{*}$ & & 0.029 & & 0.027 & \\
& 1.70 & & 1.48 & & 1.36 & \\
AC_GREY & & -0.033 & & -0.033 & & -0.032 \\
& & -1.32 & & -1.29 & & -1.26 \\
\hline & & & & & & (continued on next page)
\end{tabular}


Table 5: (continued)

\begin{tabular}{|c|c|c|c|c|c|c|}
\hline & 1 & 2 & 3 & 4 & 5 & 6 \\
\hline & FFR & FFR & FFR & FFR & FFR & FFR \\
\hline \multirow[t]{2}{*}{ AC_FIN } & & & -0.005 & -0.007 & & \\
\hline & & & -0.34 & -0.44 & & \\
\hline \multirow[t]{2}{*}{ AC_NONFIN } & & & & & 0.011 & 0.013 \\
\hline & & & & & 0.74 & 0.86 \\
\hline \multirow[t]{2}{*}{ AC_ACCT } & 0.010 & 0.008 & & & & \\
\hline & 0.58 & 0.44 & & & & \\
\hline \multirow[t]{2}{*}{ AC_MEET } & 0.084 & 0.147 & 0.100 & 0.163 & 0.107 & 0.165 \\
\hline & 0.38 & 0.66 & 0.46 & 0.74 & 0.49 & 0.76 \\
\hline \multirow[t]{2}{*}{ BOD_WOMEN } & -4.628 & $-4.577^{*}$ & -5.193 & $-5.106^{*}$ & $-5.453^{*}$ & $-5.361^{*}$ \\
\hline & -1.58 & -1.89 & -1.63 & -1.90 & -1.69 & -1.95 \\
\hline \multirow[t]{2}{*}{ AC_MALE } & -0.746 & -1.389 & -1.533 & -2.213 & -1.871 & -2.604 \\
\hline & -0.22 & -0.45 & -0.42 & -0.67 & -0.51 & -0.78 \\
\hline \multirow[t]{2}{*}{ DUALITY } & -0.143 & -0.371 & -0.040 & -0.275 & 0.014 & -0.217 \\
\hline & -0.18 & -0.46 & -0.05 & -0.36 & 0.02 & -0.28 \\
\hline \multirow[t]{2}{*}{ AC_TENURE } & -0.004 & -0.002 & -0.005 & -0.004 & -0.006 & -0.004 \\
\hline & -0.67 & -0.31 & -0.97 & -0.59 & -1.08 & -0.68 \\
\hline \multirow[t]{2}{*}{ AC_MULTI } & 0.024 & 0.062 & 0.011 & 0.045 & 0.012 & 0.045 \\
\hline & 0.13 & 0.32 & 0.06 & 0.23 & 0.06 & 0.23 \\
\hline \multirow[t]{2}{*}{ POLCON } & $-1.827^{*}$ & $-1.525^{*}$ & $-1.805^{*}$ & $-1.540^{*}$ & $-1.786^{*}$ & $-1.517^{*}$ \\
\hline & -1.94 & -1.76 & -1.96 & -1.75 & -1.92 & -1.71 \\
\hline \multirow[t]{2}{*}{ FAMILY } & -0.362 & -0.647 & -0.320 & -0.607 & -0.277 & -0.560 \\
\hline & -0.54 & -0.83 & -0.47 & -0.76 & -0.41 & -0.71 \\
\hline \multirow[t]{2}{*}{ SIZE } & 0.352 & 0.369 & 0.337 & 0.358 & 0.343 & 0.368 \\
\hline & 1.06 & 1.17 & 1.01 & 1.13 & 1.04 & 1.17 \\
\hline \multirow[t]{2}{*}{ DEBT2 } & $2.840^{* *}$ & $3.102^{*}$ & $2.591^{*}$ & $2.836^{*}$ & $2.591^{*}$ & $2.845^{*}$ \\
\hline & 2.11 & 1.89 & 1.90 & 1.78 & 1.85 & 1.77 \\
\hline $\mathrm{N}$ & 64 & 64 & 64 & 64 & 64 & 64 \\
\hline Pseudo R2 & 0.277 & 0.282 & 0.274 & 0.282 & 0.279 & 0.287 \\
\hline
\end{tabular}

Notes: Please refer to Table 1 for operational definitions; ${ }^{*},{ }^{* *}$, and ${ }^{* * *}$ present significant levels at $10 \%, 5 \%$, and $1 \%$ respectively. 
Next, we run a separate test for non-politically connected firms, as presented in Table $6 .{ }^{4}$ We find, similar to the previous tests, WOMEN has a negative relationship with the propensity of FFR.

Table 6

Non-politically connected firms

\begin{tabular}{|c|c|c|c|c|c|c|}
\hline & 1 & 2 & 3 & 4 & 5 & 6 \\
\hline & FFR & FFR & FFR & FFR & FFR & FFR \\
\hline \multirow[t]{2}{*}{ INTERCEPT } & $-36.217^{* *}$ & $-25.620^{* *}$ & $-33.434^{* *}$ & $-22.939^{*}$ & $-32.671^{* *}$ & $-23.941^{*}$ \\
\hline & -2.19 & -1.99 & -2.03 & -1.81 & -2.09 & -1.96 \\
\hline \multirow[t]{2}{*}{ AC_IND } & $0.072^{* *}$ & & $0.067^{* *}$ & & $0.066^{*}$ & \\
\hline & 2.16 & & 2.00 & & 1.86 & \\
\hline \multirow[t]{2}{*}{ AC_GREY } & & $-0.048^{*}$ & & $-0.049^{*}$ & & $-0.050^{*}$ \\
\hline & & -1.82 & & -1.89 & & -1.82 \\
\hline \multirow[t]{2}{*}{ AC_FIN } & & & 0.002 & -0.007 & & \\
\hline & & & 0.09 & -0.32 & & \\
\hline \multirow[t]{2}{*}{ AC_NONFIN } & & & & & 0.019 & 0.023 \\
\hline & & & & & 1.09 & 1.35 \\
\hline \multirow[t]{2}{*}{ AC_ACCT } & 0.021 & 0.011 & & & & \\
\hline & 0.85 & 0.40 & & & & \\
\hline \multirow[t]{2}{*}{ AC_MEET } & $0.596^{*}$ & $0.559^{*}$ & $0.587^{*}$ & $0.583^{*}$ & $0.579^{* *}$ & $0.575^{* *}$ \\
\hline & 1.93 & 1.91 & 1.92 & 1.91 & 1.99 & 2.01 \\
\hline \multirow[t]{2}{*}{ BOD_WOMEN } & $-13.325^{*}$ & $-9.988^{*}$ & $-13.514^{* *}$ & $-10.640^{*}$ & $-14.924^{* *}$ & $-11.740^{* *}$ \\
\hline & -1.83 & -1.75 & -1.97 & -1.89 & -2.15 & -2.13 \\
\hline \multirow[t]{2}{*}{ AC_MALE } & -6.398 & -5.095 & -7.099 & -6.130 & -8.679 & -7.598 \\
\hline & -1.06 & -0.97 & -1.22 & -1.19 & -1.45 & -1.45 \\
\hline \multirow[t]{2}{*}{ DUALITY } & -0.856 & -1.034 & -0.724 & -0.914 & -0.508 & -0.735 \\
\hline & -0.94 & -1.10 & -0.81 & -1.00 & -0.57 & -0.81 \\
\hline \multirow[t]{2}{*}{ AC_TENURE } & -0.014 & -0.013 & -0.016 & -0.016 & $-0.020^{*}$ & -0.019 \\
\hline & -1.29 & -0.96 & -1.58 & -1.20 & -1.88 & -1.48 \\
\hline \multirow[t]{2}{*}{ AC_MULTI } & 0.229 & 0.208 & 0.193 & 0.177 & 0.180 & 0.170 \\
\hline & 0.84 & 0.85 & 0.72 & 0.73 & 0.67 & 0.72 \\
\hline \multirow[t]{2}{*}{ FAMILY } & -0.357 & -0.765 & -0.222 & -0.689 & 0.110 & -0.446 \\
\hline & -0.43 & -0.92 & -0.26 & -0.81 & 0.13 & -0.53 \\
\hline \multirow[t]{2}{*}{ SIZE } & $1.716^{*}$ & $1.394^{*}$ & $1.681^{*}$ & $1.364^{*}$ & $1.683^{*}$ & $1.409^{*}$ \\
\hline & 1.71 & 1.74 & 1.72 & 1.74 & 1.75 & 1.75 \\
\hline
\end{tabular}


Table 6: (continued)

\begin{tabular}{lcccccc}
\hline & 1 & 2 & 3 & 4 & 5 & 6 \\
\hline DEBT2 & FFR & FFR & FFR & FFR & FFR & FFR \\
& $5.809^{* * *}$ & $5.470^{* *}$ & $5.314^{* * *}$ & $5.031^{* * *}$ & $5.076^{* * *}$ & $4.925^{* * *}$ \\
$\mathrm{~N}$ & 3.41 & 2.50 & 3.36 & 2.60 & 3.28 & 2.61 \\
Pseudo R & 47 & 47 & 47 & 47 & 47 & 47 \\
\hline
\end{tabular}

Notes: Please refer to Table 1 for operational definitions; ${ }^{*},{ }^{* *}$, and ${ }^{* * *}$ present significant levels at $10 \%, 5 \%$, and $1 \%$, respectively.

\section{CONCLUSION}

Using a sample of 64 fraud and non-fraud firms in Malaysia, we examine the association between fraudulent financial reporting and audit committee characteristics. Unlike prior studies, we focus on the effects of audit committee characteristics on fraud after the establishment of MCCG since 2001. Our analysis focuses on examining whether the establishment of the MCCG in 2001 in Malaysia has successfully reduced the occurrence of fraud. Based on previous literature, we hypothesise that audit committee characteristics such as independence, expertise, and activity will reduce the occurrence of fraud highlighting the positive effect of MCCG since 2001. This study augmented the role of the audit committee in agency theory, which stresses the importance of auditors' monitoring role in the agent-principal relationship.

We find that there is a positive association between the percentage of independent non-executive directors and fraud, suggesting independent directors might be ineffective. In contrast, we find a negative relationship between grey directors and FFR indicating the important role of inside directors in relative to outside directors. The result highlights the possible cosmetic role of independent non-executive directors in preventing fraud. The result may also highlight the re-designation of independent directors to non-independent; non-executive directors when tenure exceeds nine years can add value to the firm as having external directors with some inside information, which can help firms decrease the likelihood of FFR. We find no association between audit committee expertise and audit committee meeting with FFR.

We find a significant negative association between fraudulent financial reporting and the percentage of women on the board. The result indicates that recent regulatory changes made by the government to increase women participation in the board 
is a right move as there is evidence that women can reduce FFR. Currently, the percentage of women in board of directors in Malaysia is still less than $10 \%$, and this percentage should be increased up to $30 \%$ to help the government to achieve their target. Our result also finds significant negative association between FFR and political connection. Nevertheless, we suggest that the negative association is not to enhance shareholder value but instead treated as preferential treatment in term of either fund or power made by political connections towards fraud firms. The result also indicates that firms tend to be involved in FFR due to financial pressure. Both results provide evidence that economic motives become essential determinants for the company to be involved in FFR.

This study offers significant implications for the establishment of MCCG in Malaysia. Regulatory reforms should focus on the development of effective teams to monitor the management. Being merely independent is not a guaranteed solution for corporate malfeasance and failure. The question is not who monitors the management, but rather how to effectively monitor the management. The result also indicates that the role assignment of independent directors to non-independent, non-executive directors is a right move made by the regulators in Malaysia as the firm can capitalise the inside information possess by these directors to reduce FFR.

Our study has at least two significant limitations. First, our sample is small as the objective of our study is to investigate the effects of MCCG in mitigating FFR in Malaysia. The sample was only taken from 2001 onwards. Second, our samples relied on only one source of information which is the SC's enforcement which was released from its website.

\section{ACKNOWLEDGEMENTS}

The authors wish to express their gratitude to the Universiti Teknologi MARA (UiTM) for funding this research project through the Fundamental Research Grant Scheme (FRGS) no. 600-RMI/ARI 5/3(28/2013) and UiTM Cawangan Kelantan for the administrative support.

\section{NOTES}

1. For example, Guidance 5.2 of the Malaysian Code for Institutional Investors 2014 states that these investors should assess the quality of disclosure made by investee firms on various diversity targets and policies including gender, age and ethnicity (Ramli, 2014). 
2. We would like to note that Hasnan et al. $(2013 ; 2014)$ only has 52 fraud firms for a period of 1997-2007, while Md Nasir has 65 fraud firms from 2001-2008.

3. We could not rule that the number of the low number of observations could cause the change in results. Hence, we suggest an increase in number of observations which is beyond the scope of this paper.

4. We could not run for connected firms as the sample size is rather small $(n=11)$.

\section{REFERENCES}

Abbott, L.J., Park, Y., \& Parker, S. (2000). The effects of audit committee activity and independence on corporate fraud. Managerial Finance, 26(11), 55-68. https:// doi.org/10.1108/03074350010766990

Abbott, L.J., Parker, S., \& Peters, G.F. (2004). Audit committee characteristics and restatements. Auditing: A Journal of Practice \& Theory, 23(1), 69-87. https://doi. org/10.2308/aud.2004.23.1.69

Adams, R.B., \& Ferreira, D. (2009). Women in the boardroom and their impact on governance and performance. Journal of Financial Economics, 94(2), 291-309. https://doi.org/10.1016/j.jfineco.2008.10.007

Anderson, K.L., Gillan, S., \& Deli, D. (2003). Boards of directors, audit committees, and the information content of earnings. Working paper 2003-04, Weinberg Center for Corporate Governance. https://doi.org/10.2139/ssrn.444241

Anderson, R.C., Mansi, S.A., \& Reeb, D.M. (2004). Board characteristics, accounting report integrity, and the cost of debt. Journal of Accounting and Economics, 37(3), 315-342. https://doi.org/10.1016/j.jacceco.2004.01.004

Association for Investment Management and Research (AIMR). (1999). Letter from the Financial Accounting Policy Committee to the Blue Ribbon Committee on improving the effectiveness of corporate audit committees, New York, February.

Beasley, M., Carcello, J., \& Hermanson, D. (1999). Fraudulent financial reporting: 19871997: An analysis of U.S. public firms. Jersey City, NJ: AICPA.

Beasley, M.S., Carcello, J.V., Hermanson, D.R., \& Lapides, P.D. (2000). Fraudulent financial reporting: Consideration of industry traits and corporate governance mechanisms. Accounting Horizons, 14, 441-454. https://doi.org/10.2308/ acch.2000.14.4.441

Beasley, M. (1996). An empirical analysis of the relation between the board of director composition and financial statement fraud. The Accounting Review, 71(4), 443465.

Bhagat, S., \& Black, B. (2002). The non-correlation between board independence and long term performance. Journal of Corporation Law, 27, 231-273.

Buss, D.M. (2005). The handbook of evolutionary psychology. New York: John Wiley \& Sons.

Carcello, J.V., \& Neal, T.L. (2003). Audit committee characteristics and auditor dismissals following new going-concern reports. The Accounting Review, 78(1), 95-117. https://doi.org/10.2308/accr.2003.78.1.95 
Carcello, J.V., Hollingsworth, C.W., Klein, A., \& Neal, T.L. (2006). Audit committee financial expertise, competing corporate governance mechanisms, and earnings management. Working paper, February, University of Tennessee. https://doi. org $/ 10.2139 /$ ssrn. 887512

Chapple, J., Ferguson, C., \& Kang, D. (2009). Corporate governance and misappropriation. Journal of Forensic and Investigative Accounting, 1(2), 1-26.

Claessens, S., \& Fan, P.H.J. (2002). Corporate governance in Asia: A survey. International Review of Finance, 3(2), 71-103. https://doi.org/10.1111/1468-2443.00034

Cornelius, P. (2005). Good corporate practices in poor corporate governance systems: Some evidence from the Global Competitiveness Report. Corporate Governance: The International Journal of Business in Society, 5(3), 12-23. https://doi. org/10.1108/14720700510604661

Council, Financial Reporting. (2012). The UK stewardship code. London: Financial Reporting Council.

Croson, R., \& Gneezy, U. (2009). Gender differences in preferences. Journal of Economic Literature, 47(2), 448-474.

Dechow, P., Sloan, R., \& Sweeney, A. (1996). Causes and consequences of earnings manipulation: An analysis of firms subject to enforcement actions by the SEC. Contemporary Accounting Research, 13, 1-36.

Deli, D.N., \& Gillan, S.L. (2000). On the demand for independent and active audit committees. Journal of Corporate Finance, 6, 427-445. https://doi.org/10.1016/ S0929-1199(00)00016-X

DeZoort, F.T., \& Salterio, S.E. (2001). The effect of corporate governance experience and financial reporting and audit knowledge on audit committee member's judgements. A Journal of Practice and Theory, 20, 31-47.

Dittmar, A., \& Mahrt-Smith, J. (2007). Corporate governance and the value of cash holdings. Journal of Financial Economics, 83(3), 599-634. https://doi.org/10.1016/j. jfineco.2005.12.006

Dunn, P. (2004). The impact of insider power on fraudulent financial reporting. Journal of Management, 30(3), 397-412. https://doi.org/10.1016/j.jm.2003.02.004

Dyreng, S.D., Hanlon, M., \& Maydew, E.L. (2010). The effects of executives on corporate tax avoidance. The Accounting Review, 85(4), 1163-1189.

Eckel, C.C., \& Grossman, P.J. (2008). Forecasting risk attitudes: An experimental study using actual and forecast gamble choices. Journal of Economic Behavior \& Organization, 68(1), 1-17.

Engel, E., Hayes, R.M., \& Wang, X. (2010). Audit committee compensation and demand for monitoring of the financial reporting process. Journal of Accounting and Economics, 49(1-2), 136-154. https://doi.org/10.1016/j.jacceco.2009.08.001

Faccio, M. (2006). Politically connected firms. American Economic Review, 96, 369-386. https://doi.org/10.1257/000282806776157704

Farber, D.B. (2005). Restoring trust after fraud: Does corporate governance matter? The Accounting Review, 80(2), 539-561. https://doi.org/10.2308/accr.2005.80.2.539

Feingold, A. (1994). Gender differences in personality: A meta-analysis. Psychological Bulletin, 116(3), 429-456. https://doi.org/10.1037/0033-2909.116.3.429 
Felo, A.J., \& Solieri, S.A. (2009). Are all audit committee financial experts created equally? International Journal of Disclosure and Governance, 6(2), 150-166. https://doi. org/10.1057/jdg.2008.25

Ferreira, D. (2010). Board diversity in corporate governance: A synthesis of theory. Research and Practice, 23, 225-242.

Francis, B., Hasan, I., Park, J.C., \& Wu, Q. (2015). Gender differences in financial reporting decision making: Evidence from accounting conservatism. Contemporary Accounting Research, 32(3), 1285-1318.

Galbreath, J. (2011). Are there gender-related influences on corporate sustainability? A study of women on boards of directors. Journal of Management \& Organization, 17(1), 17-38. https://doi.org/10.1017/S1833367200001693

Ge, W., Matsumoto, D., \& Zhang, J.L. (2011). Do CFOs have style? An empirical investigation of the effect of individual CFOs on accounting practices. Contemporary Accounting Research, 28(4), 1141-1179. https://doi.org/10.1111/ j.1911-3846.2011.01097.x

Goodwin-Stewart, J., \& Kent, P. (2006). Relation between external audit fees, audit committee characteristics and internal audit. Accounting and Finance, 46(3), 387-404. https://doi.org/10.1111/j.1467-629X.2006.00174.x

Hasnan, S., \& Hussain, A.R.M. (2015). Factors associated with financial restatements: Evidence from Malaysia. Jurnal Pengurusan (UKM Journal of Management), 44, 105-116. https://doi.org/10.17576/pengurusan-2015-44-10

Hasnan, S., Rahman, R.A., \& Mahenthiran, S. (2013). Management motive, weak governance, earnings management, and fraudulent financial reporting: Malaysian evidence. Journal of International Accounting Research, 12(1), 1-27. https://doi. org/10.17576/pengurusan-2014-42-09

Hasnan, S., Rahman, R.A., \& Mahenthiran, S. (2014). Determinants of fraudulent financial reporting: Evidence from Malaysia. Jurnal Pengurusan (UKM Journal of Management), 42, 103-117.

He, L., Labelle, R., Piot, C. \& Thornton, D.B. (2009). Board monitoring, audit committee effectiveness, and financial reporting quality: Review and synthesis of empirical evidence. Journal of Forensic \& Investigative Accounting, 1(2), 1-41.

Hoechle, D., Schmid, M., Walter, I., \& Yermack, D. (2012). How much of the diversification discount can be explained by poor corporate governance? Journal of Financial Economics, 103(1), 41-60.

Hsu, H.H., \& Wu, C.Y.H. (2014). Board composition, grey directors and corporate failure in the UK. The British Accounting Review, 46(3), 215-227.

Huang, J., \& Kisgen, D.J. (2013). Gender and corporate finance: Are male executives overconfident relative to female executives? Journal of Financial Economics, 108(3), 822-839.

Jaggi, B., Leung, S., \& Gul, F. (2009). Family control, board independence and earnings management: Evidence based on Hong Kong firms. Journal of Accounting Public Policy, 28, 281-300.

Jia, C., Ding, S., Li, Y., \& Wu, Z. (2009). Fraud, enforcement action, and the role of corporate governance: Evidence from China. Journal of Business Ethics, 90(4), $561-576$. 
Johnson, S., \& Mitton, T. (2003). Cronyism and capital controls: Evidence from Malaysia. Journal of Financial Economics, 67, 351-382.

Khwaja, A., \& Mian, A. (2005). Do lenders favor politically connected firms? Rent provision in an emerging financial market. Quarterly Journal of Economics, $120(4), 1371-1411$.

Klein, A. (2002). Audit committee, board of director characteristics, and earnings management. Journal of Accounting and Economics, 33, 375-400. https://doi. org/10.1016/S0165-4101(02)00059-9

Krishnan, G., \& Peytcheva, M. (2019). The risk of fraud in family firms: Assessments of external auditors. Journal of Business Ethics, 157, 261-278. https://doi. org/10.1007/s10551-017-3687-z

Krishnan, G.V., \& Visvanathan, G. (2008). Does the SOX definition of an accounting expert matter? The association between audit committee directors' accounting expertise and accounting conservatism. Contemporary Accounting Research, 25(3), 827-858. https://doi.org/10.1506/car.25.3.7

Krishnan, J. (2005). Audit committee quality and internal control: An empirical analysis. The Accounting Review, 80(2), 649-675.

Lim, Y. (2011). Tax avoidance, cost of debt and shareholder activism: Evidence from Korea. Journal of Banking \& Finance, 35(2), 456-470.

Lo, A. W.Y., Wong, R.M.K., \& Firth, M. (2010). Can corporate governance deter management from manipulating earnings? Evidence from related-party sales transactions in China. Journal of Corporate Finance, 16, 225-235.

Md Nasir, N.A., Ali, M.J., Razzaque, R.M.R. \& Ahmed, K. (2018). Real earnings management and financial statement fraud: Evidence from Malaysia. International Journal of Accounting \& Information Management, 26(4), 508-526. https://doi. org/10.1108/IJAIM-03-2017-0039

Morrissey, J. (2000). Corporate responsibility and the audit committee. Speech presented at the General Audit Management Conference, New Orleans, 21 March.

Mustafa, S.T., \& Meier, H.H. (2006). Audit committees and misappropriation of assets: Publicly held firms in the United States. Canadian Accounting Perspectives, 5(2), 307-333. https://doi.org/10.1506/CCWW-JRWB-ECUE-YMMN

Mustafa, S.T., \& Youssef, B.N. (2010). Audit committee financial expertise and misappropriation of assets. Managerial Auditing Journal, 25(3), 208-225.

Peasnell, K.V., Pope, P.F., \& Young, S. (2000). Detecting earnings management using cross-sectional abnormal accruals models. Accounting and Business Research, 30(4), 313-326. https://doi.org/10.1080/00014788.2000.9728949

Persons, O.S. (2006). Corporate governance and non-financial reporting fraud. The Journal of Business and Economic Studies, 12(1), 27-39.

Pucheta-Martinez, M.C., \& García Meca, E. (2014). Institutional investors on boards and audit committees and their effects on financial reporting quality. Corporate Governance: An International Review, 22(4), 347-363. https://doi.org/10.1111/ corg. 12070

Raghunandan, K., Rama, D.V., \& Read, W.J. (2001). Audit committee composition, “grey directors," and interaction with internal auditing. Accounting Horizons, 15(2), $105-118$. 
Ramli, A. (2014). When differences matter. Accountants Today, 27(6), 12-15.

Rodriguez-Dominguez, L., Gallego-Alvarez, I., \& Garcia-Sanchez, I. M. (2009). Corporate governance and codes of ethics. Journal of Business Ethics, 90(2), 187-202.

Terjesen, S., Sealy, R., \& Singh, V. (2009). Women directors on corporate boards: A review and research agenda. Corporate Governance: An International Review, 173, 320-337. https://doi.org/10.1111/j.1467-8683.2009.00742.x

Vlad, M., Tulvinschi, M., \& Chiri A. (2011). The consequences of Fraudulent Financial Reporting. The Annals of the "Stefan cel Mare" University of Suceava, Romania, 11(1), 264-268.

Wan Hussin, W.N. (2009). The impact of family-firm structure and board composition on corporate transparency: Evidence based on segment disclosures in Malaysia. The International Journal of Accounting, 44, 313-333. https://doi.org/10.1016/j. intacc.2009.09.003

Xie, B., Davidson, W.N., \& DaDalt, P.J. (2003). Earnings management and corporate governance: The roles of the board and the audit committee. Journal of Corporate Finance, 9(3), 295-316. https://doi.org/10.1016/S0929-1199(02)00006-8

Zhang, Y., Zhou, J., \& Zhou, N. (2007). Audit committee quality, auditor independence, and internal control weaknesses. Journal of Accounting and Public Policy, 26(3), 300-327. https://doi.org/10.1016/j.jaccpubpol.2007.03.001 